\title{
EQUILIBRIUM STUDIES OF MERCURY (II), LEAD (II) AND CADMIUM (II) IONS INVOLVING ASPARTIC ACID AND THYMINE
}

\author{
Neeraj Kumar Tripathi \\ Department of Chemistry, PBPG College, \\ Pratapgarh City (Allahabad State University) -230 002, Uttar Pradesh, India.
}

\begin{abstract}
Equilibrium studies of $\mathrm{Hg}$ (II), $\mathrm{Pb}$ (II) and $\mathrm{Cd}$ (II) ions with aspartic acid (X) and thymine (Y) ligands in aqueous solution have been investigated. Stability constants of the complexes and the complex formation equilibria at temperature $37 \pm 1^{\circ} \mathrm{C}$ at the ionic strength $\mathrm{I}=0.1 \mathrm{M}\left(\mathrm{NaNO}_{3}\right)$ have been determined by potentiometric method. Complexes of the type MXY (1:1:1) and $M_{1} M_{2} X Y(1: 1: 1: 1)$ have been discussed.
\end{abstract}

Keywords: SCOGS, Aspartic acid, Thymine and Quaternary complexes.

\section{INTRODUCTION}

Human body contains many chelating agents such as amino acids, globins, proteins, enzymes, carboxylic acids and nucleic acidbases, which form chelate compounds ${ }^{1,2}$ with the metal ion present in the living organism. Recent research results ${ }^{3,4,5,6,7}$ have clearly demonstrated the need for comprehensive studies of metal ions and bio-ligand interaction as model systems. Multi metal-multiligand complexes studied gives clues to the roles of metal ions in many enzymic reactions, ${ }^{8,9}$. This paper deals with the investigation of $\mathrm{Hg}$ (II), Pb (II) and Cd (II) complexes with aspartic acid and thymine. The relevant stability constants have been calculated using SCOGS ${ }^{10}$ computer program.

\section{MATERIALS AND METHODS}

All the reagents were of A.R. grade and their solution were prepared in double distilled $\mathrm{CO}_{2}$ free water. Metal nitrate solutions were standardized by EDTA titration methods ${ }^{11}$ combined with ion exchange and acid base titration $^{12}$. For all the binary, ternary and quaternary systems, following solution mixture have been titrated against standardized $\mathrm{NaOH}$ $(\mathrm{O} .01 \mathrm{M})$ solution, keeping the total volume $50.0 \mathrm{ml}$ in each case:

(i) $5 \mathrm{ml} \mathrm{NaNO} 3(1.0 \mathrm{M})+5 \mathrm{ml} \mathrm{HNO}{ }_{3}(0.02 \mathrm{M})+$ $\mathrm{H}_{2} \mathrm{O}$ (ii) $5 \mathrm{ml} \mathrm{NaNO}(1.0 \mathrm{M})+5 \mathrm{ml} \mathrm{HNO}(3.02 \mathrm{M})+$ $5 \mathrm{ml} \mathrm{X}(0.01 \mathrm{M})+\mathrm{H}_{2} \mathrm{O}$

(iii) $5 \mathrm{ml} \mathrm{NaNO}(1.0 \mathrm{M})+5 \mathrm{ml} \mathrm{HNO}_{3}(0.02 \mathrm{M})+$ $5 \mathrm{ml} \mathrm{Y}(0.01 \mathrm{M})+\mathrm{H}_{2} \mathrm{O}$

(iv) $5 \mathrm{ml} \mathrm{NaNO}_{3}(1.0 \mathrm{M})+5 \mathrm{ml} \mathrm{HNO}_{3}(0.02 \mathrm{M})+5 \mathrm{ml}$ $\mathrm{X}(0.01 \mathrm{M})+5 \mathrm{ml} \mathrm{M}_{1}(\mathrm{II})(0.01 \mathrm{M})+\mathrm{H}_{2} \mathrm{O}$

(v) $5 \mathrm{ml} \mathrm{NaNO}(1.0 \mathrm{M})+5 \mathrm{ml} \mathrm{HNO}(0.02 \mathrm{M})+$ $5 \mathrm{ml} \mathrm{X}(0.01 \mathrm{M})+5 \mathrm{ml} \mathrm{M}(\mathrm{II})(0.01 \mathrm{M})+5 \mathrm{ml}$ $\mathrm{Y}(0.01 \mathrm{M})+\mathrm{H}_{2} \mathrm{O}$

(vi) $5 \mathrm{ml} \mathrm{NaNO}(1.0 \mathrm{M})+5 \mathrm{ml} \mathrm{HNO}_{3}(0.02 \mathrm{M})$ $+5 \mathrm{ml} \mathrm{X}(0.01 \mathrm{M})+5 \mathrm{ml} \mathrm{M} 2(\mathrm{II})(0.01 \mathrm{M})+$ $5 \mathrm{ml} \mathrm{Y}(0.01 \mathrm{M})+\mathrm{H}_{2} \mathrm{O}$

(vii) $5 \mathrm{ml} \mathrm{NaNO}(1.0 \mathrm{M})+5 \mathrm{ml} \mathrm{HNO}_{3}(0.02 \mathrm{M})+$ $5 \mathrm{ml} \mathrm{X}(0.01 \mathrm{M})+5 \mathrm{ml} \mathrm{M}(\mathrm{II})(0.01 \mathrm{M})+5 \mathrm{ml}$ $\mathrm{Y}(0.01 \mathrm{M})+5 \mathrm{ml} \mathrm{M}_{2}(\mathrm{II})(0.01 \mathrm{M})+\mathrm{H}_{2} \mathrm{O}$ Where, $\mathrm{M}_{1}$ (II) and $\mathrm{M}_{2}$ (II) are $\mathrm{Hg}$ (II)/Pb (II) / $\mathrm{Cd}$ (II). $\mathrm{X}=$ Aspartic acid and $\mathrm{Y}=$ Thymine Species distribution curves were obtained by plotting \% concentration of the species obtained through SCOGS against $\mathrm{pH}$. Complex formation equilibria were elucidated with the aid of the species distribution curve.

\section{RESULTS AND DISCUSSIONS}

The ligand aspartic acid is potentilly a tridentate ligand towards metal ions coordinating through a nitrogen and two carboxyl oxygen atoms. The secondary ligand thymine is chemically 2, 4-dioxo-5methylpyrimidine. It has been concluded that in general, thymine acts as a bidentate ligand. ${ }^{13}$ 
Proton ligand stability constants obtained for both the ligands and other related stability constants are presented in table 1-5. Which are in good agreement with literature values ${ }^{14}$. The formation of quaternary complexes in an aqueous solution may be conveniently expressed by the equilibrium

$$
\begin{aligned}
& \mathrm{pM}_{1}+\mathrm{qM}_{2}+\mathrm{rX}+\mathrm{sY}+\mathrm{t}(\mathrm{OH}) \\
& \left(\mathrm{M}_{1}\right)_{\mathrm{p}}\left(\mathrm{M}_{2}\right)_{\mathrm{q}}(\mathrm{X})_{\mathrm{r}}(\mathrm{Y})_{\mathrm{s}}(\mathrm{OH})_{\mathrm{t}}
\end{aligned}
$$

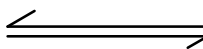

The overall stability constant is given by $\boldsymbol{\beta}_{\text {pqrst }}=$

$$
\frac{\left[\left(\mathrm{M}_{1}\right)_{\mathrm{p}}\left(\mathrm{M}_{2}\right)_{\mathrm{q}}(\mathrm{X})_{\mathrm{r}}(\mathrm{Y})_{\mathrm{s}}(\mathrm{OH})_{\mathrm{t}}\right]}{\left[\mathrm{M}_{1}\right]^{\mathrm{p}}\left[\mathrm{M}_{2}\right]^{\mathrm{q}}[\mathrm{X}]^{\mathrm{r}}[\mathrm{Y}]^{\mathrm{s}}[\mathrm{OH}]^{\mathrm{t}}}
$$

Where the stoichiometric numbers $p, q, r, s$ are either zero or positive integer and $t$ is a negative integer for a protonated species, positive for a hydroxo or a deprotonated species and zero for a neutral species.

The speciation curves indicate the formation of heterobinuclear complex species $M_{1} M_{2} X Y$ in the $\mathrm{pH}$ range $-2.6-9.5$, according to the following equilibria

$$
\begin{aligned}
& \mathrm{M}_{1}^{2+}+\mathrm{M}_{2}^{2+}+[\mathrm{XH}]^{2-}+\mathrm{YH} \leftrightharpoons \\
& {\left[\mathrm{M}_{1} \mathrm{M}_{2} \mathrm{XY}\right]+2 \mathrm{H}^{+}}
\end{aligned}
$$

It is clear from the speciation curves that formation of heterobimetallic complexes is preferred over the homometallic complexes. the following species have been considered to exist in the equalibria $\mathrm{Pb}(\mathrm{II})-\mathrm{Cd}(\mathrm{II})-\mathrm{X}-\mathrm{Y}$ $(1: 1: 1: 1)$

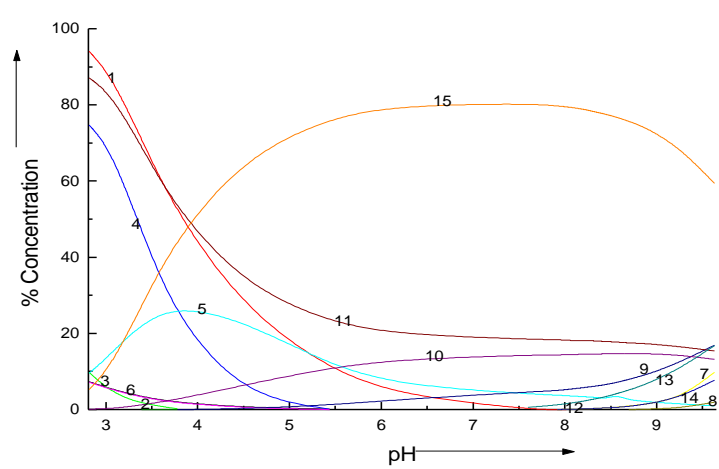

Fig. 1: Distribution Curves of 1:1:1:1 Pb (II)-Cd (II) $-\mathrm{X}-\mathrm{Y}$ System

(1) $\mathrm{Cd}^{2+}$ (II) (2) $\mathrm{Pb}^{2+}$ (II) (3) $\mathrm{H}_{3} \mathrm{X}$ (4) $\mathrm{H}_{2} \mathrm{X}$ (5) $\mathrm{HX}$ (6) $\mathrm{YH}(7) \mathrm{Cd}(\mathrm{OH})_{2}(8) \mathrm{Cd}(\mathrm{OH})^{+}$

(9) $\mathrm{Pb}(\mathrm{OH})_{2}(10) \mathrm{CdY}(11) \mathrm{PbX}(12) \mathrm{PbY}$ (13)CdXY (14) PbXY(15)PbCdXY

\section{CONCLUSIONS}

On the basis of experimental results we have to say that, ternary and quaternary complexes of mercury are more stable in comparison of lead and cadmium. The overall stability constants of ternary (MXY) and quaternary systems $\left(M_{1} M_{2} X Y\right)$ have been found to fallow the following order:

Ternary System: $\mathrm{HgXY}>\mathrm{PbXY}>\mathrm{CdXY}$ Quaternary System: $\mathrm{Hg}-\mathrm{Pb}-\mathrm{XY}>\mathrm{Hg}-\mathrm{Cd}-\mathrm{XY}$ $>\mathrm{Cd}-\mathrm{Pb}-\mathrm{XY}$

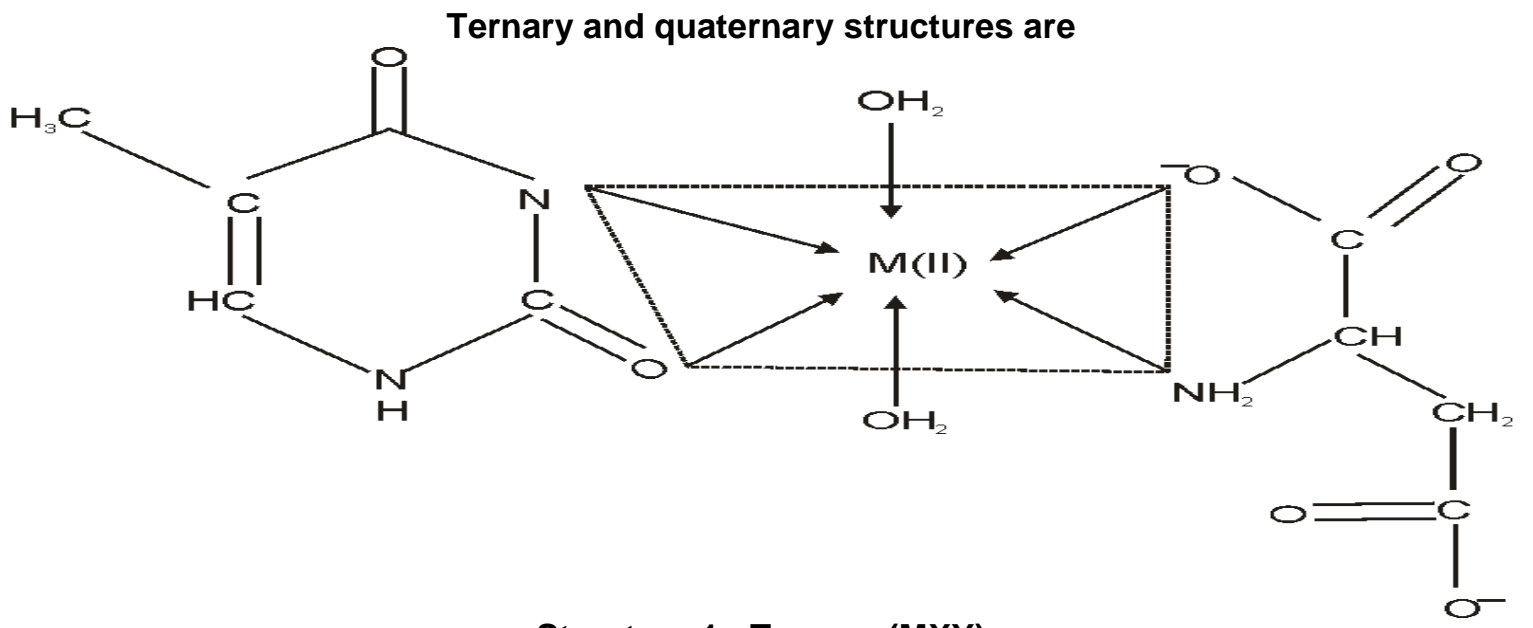

Structure 1: Ternary (MXY) 


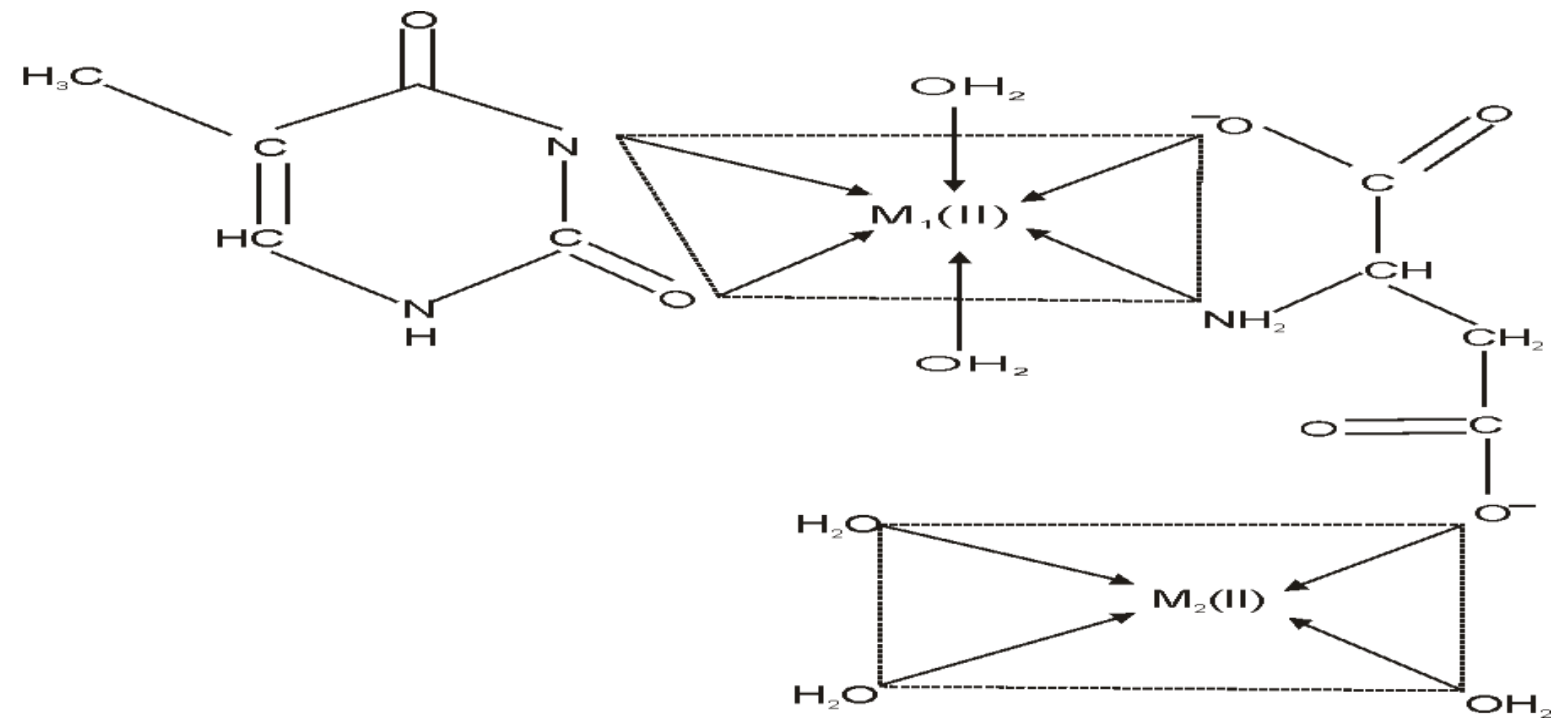

Structure 2: Quaternary $\left(M_{1} M_{2} X Y\right)$

Table 1: Proton-ligand formation constant (log $\left.\beta_{0000 t} / \log \beta_{000 s t}\right)$ of Aspartic acid and Thymine at $37 \pm 1^{\circ} \mathrm{C}, \mathrm{I}=0.1 \mathrm{NaNO}_{3}$

\begin{tabular}{|c|c|}
\hline Complex & log $\beta_{\text {oorot }} /$ log $\beta_{\text {000st }}$ \\
\hline $\mathrm{H}_{3} \mathrm{X}$ & 15.26 \\
\hline $\mathrm{H}_{2} \mathrm{X}$ & 13.33 \\
\hline $\mathrm{HX}$ & 9.63 \\
\hline $\mathrm{YH}$ & 9.94 \\
\hline
\end{tabular}

Table 2: Hydrolytic constants

$\left(\log \beta_{\text {pooot }} / \log \beta_{0 \mathrm{qo0t}}\right) \mathbf{M}^{2+}$ (aq.) ions

\begin{tabular}{|c|c|c|c|}
\hline Complex & Hg & Pb & Cd \\
\hline $\mathrm{M}(\mathrm{OH})^{+}$ & -3.84 & -9.84 & -6.89 \\
\hline $\mathrm{M}(\mathrm{OH})_{2}$ & -6.38 & -15.54 & -14.35 \\
\hline
\end{tabular}

Table 3: Metal-Ligand constants (log $\beta_{\text {poroo }} / \log \beta_{0 q r o 0} /$ $\left.\log \beta_{\text {pooso }} / \log \beta_{0 q 0 s 0}\right)$ Binary System

\begin{tabular}{|c|c|c|c|}
\hline Complex & $\mathbf{H g}$ & $\mathbf{P b}$ & $\mathbf{C d}$ \\
\hline $\mathrm{MX}$ & 13.08 & 11.60 & 4.38 \\
\hline $\mathrm{MY}$ & 13.42 & 12.77 & 11.45 \\
\hline
\end{tabular}

Table 4: Metal-Ligand constants $\left(\log \beta_{\text {porso }} / \log \beta_{\text {ogrso }}\right):$ Ternary System (1:1:1) Complex MXY Hg Pb 18.08

Table 5: Metal-Ligand constants $\left(\log \beta_{\text {pqrst }}\right)$ : Quaternary System $(1: 1: 1: 1)$

\begin{tabular}{|c|c|c|c|}
\hline Complex & Hg-Pb & Hg-Cd & Cd-Pb \\
\hline $\mathrm{M}_{1} \mathrm{M}_{2} \mathrm{XY}$ & 28.81 & 27.80 & 26.82 \\
\hline
\end{tabular}




\section{REFERENCES}

1. Grvan FL. Chelating Agents and Metal Chelates (Ed. F.P. Dwyer and D.P. Mellor) Academic Press, New York. 1964;7:283.

2. Birch J. Handbook on Toxicity of inorganic compounds. Marcel Dekker, New York. 1988;383.

3. Tripathi NK and Krishna V. Journal of Ultra Chemistry. 2011;7(2):317-319.

4. Doja A and Roberts W. Immunizations and autism: a review of the literature. Can J Neural Sci. 2006;33(4):341-346.

5. Tripathi NK and Krishna V. Journal of Ultra Chemistry. 2013;9(1):83-86.

6. Kumar $\mathrm{K}$ and Tripathi NK. IJRANSS. 2018;6(3):129-136.

7. Shukla BK, Kumar R, Verma $S$ and Krishna V. IJRPC. 2016;6(4):643-649.

8. Sigel H. Angew Chem Int Ed Engl. 1975;14:394.
9. Sigel H. Chemistry of Metals in Biological System. Journal of the European Science Foundation. 1991;24:16-17.

10. Sayce IG. Talanta. 1968;15:13971411.

11. Welcher FJ. The analytical uses of ethylene diamante tetraacetic acid, Van D. Nostarand Company, New York. 1957;169.

12. Kolthoff IM, Sandell EB, Meena EJ and Bruckenstein S. Quantitative chemical analysis. Macmilan, London. 1969;41.

13. Jonsson MJ. Rec Trav chim. 1957, 76:827.

14. Perrin DD. Stability Constants of Metal ion Complexes. Pergamon. New York. 1979. 